\title{
Children as caregivers: a research study on the perspective of nurses from the Autonomous Region of Madeira
}

\author{
Crianças como cuidadores: uma investigação sobre a perspetiva dos enfermeiros \\ da Região Autónoma da Madeira \\ Niños como cuidadores: una investigación sobre la perspectiva de los enfermeros \\ en la Región Autónoma de Madeira \\ Carla Andreia Pinto*; Ana Sofia Filipe Marote**; Pedro Miguel Nunes Pedrosa***; Maria do Céu Barbieri Figueiredo****
}

\begin{abstract}
Background: In Portugal, there are no records of children as caregivers. The international literature highlights that this is an important area of intervention for health professionals.

Objectives: To analyze the primary care nurses' perspective about young caregivers in the Autonomous Region of Madeira and identify areas of intervention.

Methodology: A quantitative and descriptive study was conducted based on a questionnaire applied to a sample of 157 nurses of the Autonomous Region of Madeira.

Results: Among the participating nurses, 23\% had already contacted with young caregivers, 29\% with young caregivers caring for their grandparents, $25 \%$ with young caregivers caring for parents with mental disorders, and $21 \%$ with young caregivers caring for parents with chronic diseases. The following areas of nursing intervention were identified, education, skills training, individual support and counselling. Conclusion: The aging of the population and the high prevalence of mental disorders increase the probability of children assuming the role of caregivers. We recommend that this study be replicated in mainland Portugal. Qualitative studies should also be conducted on the role of the dependent person and the young caregiver.
\end{abstract}

Keywords: child; caregivers; nurses; role of the nursing professional

\section{Resumo}

Enquadramento: Não há registos, em Portugal, sobre crianças como cuidadoras. A literatura internacional realça que esta é uma área importante de intervenção dos profissionais de saúde.

Objetivos: Analisar a perspetiva dos enfermeiros dos cuidados de saúde primários da Madeira sobre a problemática das crianças como cuidadoras e conhecer as áreas de intervenção de enfermagem junto destas.

Metodologia: Estudo quantitativo, descritivo, com aplicação de um questionário a uma amostra de 157 enfermeiros da Região Autónoma da Madeira

Resultados: Dos enfermeiros, 23\% refere que já contactou com crianças cuidadoras, crianças que cuidam dos avós (29\%), dos pais com doença psiquiátrica (25\%) e dos pais com doença crónica (21\%). Foram identificadas como áreas de intervenção de Enfermagem o ensino, treino de competências, suporte individual e aconselhamento.

Conclusão: O envelhecimento e as doenças psiquiátricas aumentam a probabilidade de uma criança assumir o papel de cuidadora. Propomos a replicação desta investigação em Portugal continental assim como de estudos de natureza qualitativa, explorando o papel da pessoa dependente e da criança cuidadora.

Palavras-chave: criança; cuidadores; enfermeiros; papel do profissional de enfermagem

\footnotetext{
* RN, Clinique Saint Louis, Chambourcy, 78300, France [carla.pinto.enf@gmail.com]. Contribution to the article: literature review; study design; questionnaire design; data collection; data analysis and discussion; article writing. Address for correspondence: 13 Grande Rue 1 er Etage, Chambourcy, 78300, França. ** RN, Vascular Surgery, Mid Essex Hospital Services, NHS Trust Broomfield Hospital, CM1 7ET Essex, England [anasofiamarote@gmail.com]. Contribution to the article: literature review; study design questionnaire design; data collection; data analysis and discussion; article writing.

**** RN, Medicine 1C, Hospital Center Lisboa Norte, EPE - Hospital of Santa Maria, 1649-035, Lisboa Portugal [pedrosapedrosa27@hotmail.com]. Contribution to the article: literature review; study design; questionnaire design; data analysis and discussion; article writing.

***** Ph.D. Professor, Nursing School of Porto, 4200-072. Porto. Portugal [ceu@esenf.pt. Contribution to the article: literature review; study design; questionnaire design; data analysis and discussion.
}

\section{Resumen}

Marco contextual: En Portugal no hay registros sobre los niños como cuidadores. La literatura internacional destaca que esta es un área importante de intervención de los profesionales de la salud.

Objetivos: Analizar la perspectiva de los enfermeros de atención primaria de Madeira (Portugal) sobre la problemática de los niños como cuidadores y conocer las áreas de intervención de la enfermería.

Metodología: Se trata de un estudio cuantitativo de perfil descriptivo para el cual se autoadministró un cuestionario a una muestra ocasional de 157 enfermeros de Madeira.

Resultados: El 23 \% de los enfermeros indica que ya tuvo contacto con niños cuidadores. Las situaciones identificadas fueron: niños que cuidan de los abuelos (29\%); niños que cuidan de los padres con enfermedad psiquiátrica ( $25 \%$ ), y niños que cuidan de los padres con enfermedad crónica (21\%). Las áreas de intervención de la enfermería identificadas fueron: enseñanza, práctica de competencias, apoyo individual y asesor.

Conclusión: El envejecimiento y las enfermedades psiquiátricas aumentan la probabilidad de que los niños asuman el papel de cuidadores. Se propone realizar esta misma investigación en Portugal Continental, así como estudios cualitativos para explorar el papel de la persona dependiente y del niño cuidador.

Palabras clave: niños; cuidadores; percepción; enfermeras; papel del profesional de enfermería

Received for publication: 26.10 .15 Accepted for publication: 28.03 .16 


\section{Introduction}

The percentage of the population in need of health care provision is estimated to be higher than the percentage of active population (Siskowski, 2006). With the increase in the number of single-parent and nuclear families, when one of the family members becomes ill and there is the need to ensure the role of caregiver, the evidence indicates that children take on this role (Marote, Pinto, Vieira, Barbieri-Figueiredo, \& Pedrosa, 2012).

The importance of social support to deal with chronic diseases within the family has long been an object of research and scientific discussion. On the other hand, the way in which family roles are restricted has been a neglected area, which is why this issue has sparked greater scientific attention in Nursing (Metzing-Blau, Schnepp, Hübner, \& Bücher, 2006).

Young caregivers are children who provide care in a significant and regular way to family members living in the same house and who need help due to chronic physical or mental disease, age-associated dependence, or other conditions. These children take on a certain responsibility, often by providing support to the activities of daily living, which, at least in Western societies, are not usually intended for them. They are usually children and adolescents aged up to 18 years (Becker \& Becker, 2008; Marote et al., 2012; Siskowski, 2006; Warren, 2007).

This type of care can include one or more of the following areas: personal care (bathing, feeding, dressing...), medication management, household care, supervision, assistance in going to health care services, and emotional support. Children can provide direct or indirect care and the fact that they take on the responsibilities of an adult's health is in itself caring (Siskowski, 2006; Robson, Ansell, Huber, Gould, \& van Blerk, 2006; Obadina, 2010). It should be noted that this role is closely related to the demographic and socio-cultural context of the populations (Becker, 2007; Obadina, 2010).

Several studies have revealed the number of children caregivers, but most of them have concluded that we know very little about the actual magnitude of the issue of children as caregivers (Aldridge \& Becker, 1994; Gays, 2000). As a result of the breakdown of the family network and the reduced number of children in the family, children may be the only ones available to provide care.
It is evident that the Portuguese population is increasingly delaying starting a family. The employment and marriage prospects are postponed and, consequently, the beginning of the parental cycle is delayed. In 2005, the mean age for having the first child was 30 years. If we add the increasingly aged population (in Portugal, the older population is expected to reach $32 \%$ by 2050), with the increasingly earlier onset of chronic diseases, i.e. between 40 and 50 years of age, accompanied by a certain level of dependence, a large percentage of children has a high probability of becoming young caregivers (Instituto Nacional de Estatística, 2011).

Families have extreme difficulty in accepting the provision of care by people from outside the family context and some care receivers are reluctant to involve their neighbors or friends. This is due to the fact that they prefer their experiences to stay within the family. Even so, in the long term, adults allow this support, unlike children who are not so willing to accept help from neighbors or even social support (Aldrige \& Becker, 1994).

This research is the result of an integrative literature review (Marote et al., 2012) in which we observed the growing international evidence on this issue and the lack of studies in Portugal. Therefore, the fact that this study was conducted in the Autonomous Region of Madeira can bring into discussion this forgotten and hidden reality in Portugal. The objectives of this study were to analyze the perspective of the primary care nurses of the Autonomous Region of Madeira (ARM) about the issue of children as caregivers and identify the areas for intervention detected by these nurses during their contact with these children.

\section{Background}

The knowledge about the role of young caregivers is extremely limited. In 2001, there were 175,000 young caregivers in the United Kingdom (Obadina, 2010). However, it is estimated that there are currently about 700,000 young caregivers in the United Kingdom, which corresponds to $8 \%$ of the total number of children (Marote et al., 2012; Howard, 2010). In Australia, 169,900 young caregivers have been identified (3.6\%), 1.3 to 1.4 million (3.2\%) aged between 8 and 18 years in the United States of America (USA; Obadina, 2010) and over 200,000 in Germany 
(Metzing-Blau \& Schnepp, 2008). In Portugal, data point to around 66,000 young caregivers (3\% of the total number of children).

In addition to the lack of data on this issue, there are certain factors in today's societies that force the child to provide care to an adult, such as the high prevalence of single-parent families, the increased average life expectancy, the lack of another person to assume the caregiver's role (Siskowski, 2006), the difficulty to accept care provision by people from outside the family context (Aldridge \& Becker, 1994), the limited financial and material resources, the nature and extent of the disease/disability, the increased mean age of first-time motherhood the concept of family and family values, the expectations/ beliefs, and the structure and dynamics of family relationships (Warren, 2007; Becker, 2007; Metzing-Blau et al., 2006).

Young caregivers are difficult to identify due to their silence. The evidence points to the lack of support and assistance from family, friends, neighbors and health professionals to young caregivers (Schlarmann, Metzing-Blau, \& Schnepp, 2011).

Although the health professionals' knowledge about young caregivers has been increasing, it remains invisible since these children's needs have not yet been identified and met (Obadina, 2010; Schlarmann et al., 2011). This negligence may be related to time constraints, insufficient resources and knowledge about this reality, and an underestimation or disregard for their role as caregivers (Adridge \& Becker, 1994; Obadina, 2010; Schlarmann et al., 2011; Marote et al., 2012).

Despite these difficulties, nursing professionals should pay attention to this reality since the role as caregiver represents an addition to the normal roles of an individual. Thus, when the behavioral expectations change dramatically, it implies a reorganization of the caregiver's daily routine (Schumacher \& Meleis, 2007). According to these authors, taking on the role as caregiver is a specific type of transition in family roles that occurs in response to changes in the health status, in relationships, expectations or skills, which lead to a decrease in the capacity for self-care of the affected family member, who will require greater care from others.

\section{Research Question}

The following research questions were formulated for this study: What is the perspective of primary care nurses of the ARM about the issue of children as caregivers? What were the needs of young caregivers and their families? Were any nursing interventions developed aimed at these children?

\section{Methodology}

A quantitative descriptive study was conducted with a random sample of 157 primary care nurses working in 47 health care centers of the ARM.

Data were collected through a self-administered questionnaire designed by the authors, based on a literature review (Marote et al., 2012). The questionnaire was composed of nine multiple choice/ closed-ended questions in which participants were asked to justify their answers in order for us to understand their perspective about the reality of young caregivers, characterize these caregivers and identify the nurses' interventions aimed at these children. The questionnaire was first evaluated in a pilot test with nurses working in the health care centers of Porto, belonging to the Regional Health Administration of the North, who had similar characteristics to those included in the sample.

In order to ensure the ethical-legal issues, the Ethics Committee of the Health Service of the Autonomous Region of Madeira (Serviço de Saúde da Região Autónoma da Madeira - SESARAM) was contacted, having approved and validated the project on 2 December 2011.

Data were collected between April and July 2012. The inclusion criteria were: being a primary care nurse working in the ARM and being available to participate in the study.

Two researchers went to the ARM and presented the study to potential participants. The questionnaires were distributed in the 47 health care centers. Subsequently, we collected the 157 completed questionnaires, as well as the respective informed consent.

The data collected were inserted in a Microsoft Excel sheet. Quantitative data were analyzed through the 
analysis of the frequency distribution, expressed in percentage (Minayo, 2014). In the qualitative data analysis, the answers were organized according to similarities and patterns.

\section{Results}

Out of the total 420 nurses from the 47 health care centers of the ARM, 157 nurses participated in the study, with a response rate around $37 \%$. This sample was composed of 140 female nurses (89\%) and 17 male nurses (11\%). The mean age was 36 years, with a minimum age of 22 years and a maximum age of 64 years. The mean time of professional experience in a health care center was 10 years.

When asked if they believed that a child could take on the role of caregiver, 34 (22\%) of the 157 nurses answered that a child can take on the role of caregiver, 117 (74\%) nurses answered that a child cannot perform these functions, and 6 (4\%) nurses did not answer.

As shown in Table 1, the 34 nurses gave several reasons for believing that a child could be a caregiver: 27 (79\%) nurses emphasize that age is a very important factor in whether he/she can take on or not the caregiver's role, 12 (35\%) nurses answered that it depends on the child's maturity to perform the caregiver's role, six (18\%) nurses argued that taking on this role depends on the nature of care, and other six nurses said that the child can take on this role as a last resource. Finally, three (9\%) nurses answered that the child can take on the role of caregiver if he/ she is both physically and emotionally able to do it, other three nurses argue that the child can assume this role if supervised by adults, and one (3\%) nurse argues that the child or adolescent can be a caregiver if her/his life experience is compatible with caring for another person. Out of the nurses who gave a positive answer, three (9\%) nurses did not justify their answer.

Table 1

Distribution of the nurses according to the reason for believing that a child can take on the role of caregiver, 2012

\begin{tabular}{lcc}
\hline Reason & $N$ & $\%$ \\
\hline Age & 27 & 79 \\
Enough maturity & 12 & 35 \\
Nature of care & 6 & 18 \\
As a last resource & 6 & 18 \\
Physical and emotional capacity & 3 & 9 \\
When supervised by an adult & 3 & 9 \\
Enough life experience & 1 & 3 \\
No answer & 3 & 9 \\
\hline Total & 34 & 100 \\
\hline
\end{tabular}

The reasons put forward by the 117 nurses who believed that children cannot assume the caregiver's role overlap, although in negative terms. Out of these nurses, 39 (33\%) nurses argued that the child lacks maturity and responsibility to care for another person, 29 (25\%) nurses justified their answer with the poor physical, intellectual and emotional development of a child, and 13 (12\%) nurses argued that adults are the ones who should take on this role. Age, lack of skills, and the fact that the child needs surveillance and live their childhood were the arguments presented by seven (6\%) nurses for each item. Six (5\%) of the nurses claimed that it is against children's rights and three (3\%) nurses argued that children lack knowledge and experience in caring. One (1\%) of the nurses argued that this is not part of European culture and one nurse also argued that the caregiver's role is a task too heavy for children, as shown in Table 2. Eleven (9\%) nurses did not answer. 
Table 2

Distribution of the nurses according to the reason for believing that a child cannot take on the role of caregiver, 2012

\begin{tabular}{lcc}
\hline Reason & $N$ & $\%$ \\
\hline Immaturity and low responsibility & 39 & 33 \\
Poor physical, intellectual and emotional development & 29 & 25 \\
Adult's responsibility & 13 & 12 \\
Age & 7 & 6 \\
Lack of skills & 7 & 6 \\
Still needs support and surveillance - live their childhood & 7 & 6 \\
Against children's rights & 6 & 5 \\
Lack of knowledge and experience in caring & 3 & 3 \\
Not part of European culture & 1 & 1 \\
Heavy task & 1 & 1 \\
No answer & 11 & 9 \\
\hline Total & 117 & 100 \\
\hline
\end{tabular}

As Table 3 shows, 115 (73\%) nurses had never contacted with a young caregiver in their professional practice. On the other hand, 25 (16\%) nurses stated that they had already contacted with young caregivers

Table 3 in their professional practice, and 11 (7\%) nurses said that they had never contacted with a young caregiver, but that another nurse had told them about the situation.

Distribution of the nurses according to their contact with a young caregiver, 2012

\begin{tabular}{lcc}
\hline Answer & $N$ & $\%$ \\
\hline Yes & 25 & 16 \\
No & 115 & 73 \\
No, but another nurse told me about the situation & 11 & 7 \\
No answer & 6 & 4 \\
\hline Total & 157 & 100 \\
\hline
\end{tabular}

According to Table 4, eight (22.5\%) of the nurses who had already contacted with young caregivers, or had knowledge of the situation through another nurse, reported that the children provided care to dependent grandparents, seven (19\%) nurses reported that the children provided care to parents with mental disorders, and six (17\%) nurses reported that the children provided care to parents with unspecified chronic diseases. Seven (19\%) nurses did not answer and eight (22.5\%) nurses described situations of caring that do not fall under the definition of a young caregiver, namely caring for younger siblings.

Table 4

Sample distribution according to the nurses' description of the young caregivers' situation, 2012

\begin{tabular}{lcc}
\hline Answer & $N$ & $\%$ \\
\hline Caring for dependent grandparents & 8 & 22.5 \\
Caring for parents with mental disorders & 7 & 19 \\
Caring for parents with unspecified chronic diseases & 6 & 17 \\
No answer & 7 & 19 \\
Answer in disagreement with the definition & 8 & 22.5 \\
\hline Total & 36 & 100 \\
\hline
\end{tabular}


Table 5 shows the nursing care needs identified by the nurses who contacted with young caregivers. Thus, eight (53\%) nurses identified the need for intervention in education and skills training, seven (47\%) nurses identified the need for individual support and advice, five (33\%) nurses identified the need for social contact and leisure, four (27\%) nurses identified the need for information (e.g., their parents medical condition' diseases, available services, among others), three (20\%) nurses identified the need for practical assistance, and one (7\%) nurse identified the need for support from relatives. One of the nurses (7\%) had no direct contact with a young caregiver, while another nurse argues that none of the response options corresponded to the needs of young caregivers.

\section{Table 5}

\section{Sample distribution according to the young caregivers' needs identified by the nurses, 2012}

\begin{tabular}{lcc}
\hline Answer & $N$ & $\%$ \\
\hline Education and skills training & 8 & 53 \\
Individual support and advice & 7 & 47 \\
Social contact and leisure & 5 & 33 \\
Information (e.g., their parents' medical condition diseases, available services, etc.) & 4 & 27 \\
Practical assistance & 3 & 20 \\
No contact with the child & 1 & 7 \\
Support from relatives & 1 & 7 \\
None of the above & 1 & 7 \\
\hline
\end{tabular}

\section{Discussion}

In this study, approximately $22 \%$ of the nurses recognize that a child can assume the role of caregiver. Of the $74 \%$ of the nurses who feel that the child must not assume the caregiver's role, 33\% argue that the child lacks the maturity and responsibility for taking care of others, $25 \%$ consider that the child has poor physical, intellectual and emotional development, and 12\% think that it is a responsibility for adults and not for children. These results are consistent with the results of other studies highlighting that health care professionals have possibly neglected this reality due to lack of time, resources, and knowledge about the existence of this reality, as well as an underestimation or disregard for the role of young caregivers (Marote et al., 2012; Obadina, 2010; Aldridge \& Becker, 1994). In this study, we found that $23 \%$ of the nurses had already contacted with a young caregiver in their professional practice or were told about the situation by another nurse. This percentage differs from the one found in studies carried out in the USA, UK and Australia (Becker \& Becker, 2008; Obadina, 2010; Metzing-Blau et al., 2006). Our study emphasizes that this discrepancy is based on the extremely limited knowledge about this issue. Nevertheless, the number of young caregivers in the ARM is estimated to be higher than those officially recognized (Howard, 2010; Metzing-Blau et al., 2006).

Among the nurses who contacted with a young caregiver or were told about the situation by another nurse, $22.5 \%$ of the nurses reported that the children provided care to their dependent grandparents due to age-associated limitations, 19\% reported that children provided care to parents with mental disorders, and 17\% reported that children provided care to parents with unspecified chronic diseases. The characteristics of the dependent person found in this analysis are corroborated by the literature (Warren, 2007; Robson et al., 2006). It is worth mentioning that $22.5 \%$ of the participants reported having contacted with this situation, but the situation encountered does not correspond to the definition of young caregivers, since caring for healthier younger siblings is part of the natural life-cycle, and the situations of adolescent mothers relate to the nursing focus of parenthood. This percentage indicates once again the lack of knowledge and attention given to this reality.

With regard to the needs of young caregivers identified by the nurses who had contacted with this reality, $53 \%$ of the nurses highlighted the need for education and skills training, $47 \%$ of the nurses pointed out the need for individual support and advice, 33\% of the nurses recognized the need for 
social contact and leisure, $27 \%$ of them identified the need for information (e.g., their parents' medical condition diseases, available services, among others), $20 \%$ identified the need for practical assistance, and $7 \%$ of the nurses believed that the young caregiver needs support from relatives. Once again, these data are consistent with the scientific evidence that defines three categories for the needs of young caregivers: psychological support, education with practical training, and information and social support systems (Becker \& Becker, 2008; Marote et al., 2012; Obadina, 2010; Metzing-Blau et al., 2006). In the ARM, the type of tasks and responsibilities of young caregivers are similar to those of adult caregivers, as confirmed by the studies on this issue (Warren, 2007; Becker, 2007; Obadina, 2010).

As a limitation of this study, we point out the lack of familiarity with the concept of young caregiver, although it was clearly explained in the questionnaire.

\section{Conclusion}

This study addressed an underexplored and underdiscussed issue in the nursing community. Although nurses have different opinions, we found that young caregivers are a reality in our country, which the nursing community cannot overlook. In this study, most of these children care for their grandparents or parents with mental disorders. According to the nurses who contacted with this reality, these children have several needs, namely concerning education and skills training, individual support, social contact, information, practical assistance, and family support. It seems clear that young caregivers worldwide may have more in common than what separates them geographically and culturally, since their tasks and responsibilities are very similar. It is up to us, nurses, to consider these children as the targets of our care and as unique beings with specific needs and integrated into their own families and social situations.

Nurses have a major responsibility in ensuring the psychosocial well-being of these children, which is why we should continue to invest in research so as to determine the best way to intervene and help these children to have a healthy biopsychosocial development. A more in-depth knowledge about the activities performed by the young caregivers will allow a proactive approach to this issue, contributing to future prevention and individualized care interventions. Therefore, in addition to the relevance of the replication of this study in mainland Portugal, qualitative studies should also be conducted on the role of the dependent person and the caregiver, identifying the factors facilitating and hampering this therapeutic relationship.

\section{References}

Aldridge, J., \& Becker, S. (1994). My child, my carer: The parents' perspective. Loughborough, England: Loughborough University

Becker, F., \& Becker, S. (2008). Service needs and delivery following the onset of caring amongst children and young adults: Evidenced based review. Cheltenham, England: Commission for Rural Communities

Becker, S. (2007). Global perspectives on children's unpaid caregiving in the family research and policy on 'young carers' in the UK, Australia, the USA and Sub-Saharan Africa Global Social Policy, 7(1), 23-50. doi: 10.1177/1468018107073892

Gays, M. (2000). Getting it right for young carers in the ACT. In Family Futures: Issues in research and policy. In 7th Australian Institute of Family Studies Conference, Sydney, 24-26 Julho, Austrália.

Howard, D. (2010). Number of child carers "four times previous estimate". Retrieved from http://www.bbc.com/news/ education-11757907

Instituto Nacional de Estatística. (2011). Censos 2011: Resultados provisórios. Lisboa, Portugal: Autor.

Marote, A. S., Pinto, C. A., Vieira, M. R., Barbieri-Figueiredo, M. C., \& Pedrosa, P. M. (2012). Children as carers: An integrative review. Revista Latino-Americana de Enfermagem, 20(6), 1196-1205. doi: 10.1590/S0104-11692012000600023

Metzing-Blau, S., Schnepp, W., Hübner, B., \& Bücher, A. (2007). Die lücke füllen und in Bereitschaft sein: Kinder und jugendliche als pflegende Angehörige. Pflege \& Gesellschaf. 11(4), 351373. Retrieved from http://www.ig-pflege.at/downloads/ news/2010/Kinder-und-Jugendliche-PfleGe406Metzing.pdf

Metzing-Blau, S., \& Schnepp, W. (2008). Young carers in Germany: To live on as normal as possible: A grounded theory study. BMC Nursing, 7(15). doi: 10.1186/1472-6955-7-15

Minayo, M. C. (2014). O desafio do conbecimento: Pesquisa qualitativa em saúde (11ª ed.). São Paulo, Brasil: Hucitec.

Obadina, S. (2010). Parental mental illness: Effects on young carers. British Journal of School Nursing, 5(3),135 -139.

Robson, E., Ansell, N., Huber, U. S., Gould, W. T., \& van Blerk, L. (2006). Young caregivers in the context of the HIV/AIDS pandemic in sub-Saharan Africa. Population, Space and Place, 12(2), 7-22. doi:10.1002/psp.392 
Schlarmann, J. G., Metzing-Blau, S., \& Schnepp, W. (2011). Implementing and evaluating the first German young-carers project: Intentions pitfalls and the need for piloting complex interventions. The Open Nursing Journal, 5, 38-44. doi: 10.2174/18744334601105010038

Schumacher, K., \& Meleis, A. (2007). Transitions: A central concept in nursing. Journal of Nursing Scholarship. 26(2), 119-127. doi: 10.1111/j.1547-5069.1994.tb00929.x
Siskowski, C. (2006). Young caregivers: Effect of family health situation on school performance. The Journal of School Nursing, 22(3), 163-169. doi: 10.1177/10598405060220030701

Warren, J. (2007). Young carers: Conventional or exaggerated levels of involvement in domestic and caring tasks? Children \& Society, 21(2), 136-146. doi: 10.1111/j.10990860.2006.00038.x 